\title{
Persistence of Ulama in Progress of Islam in East Kotawaringin
}

\author{
Rizki Amalia Nur Anwari \\ Magister Ilmu Komunikasi \\ Universitas Sebelas Maret (UNS) \\ Surakarta, Indonesia \\ writerizma@gmail.com
}

\begin{abstract}
The island of Borneo as widely known is the second largest island in Indonesia after Papua. The Dayak ethnic is the major inhabitant of the island along with other ethnics including Javanese, Banjarnese, and Maduranese. Yet the Dayak ethnic comprises a number of sub-ethnic such as Dayak Bakumpai, Dayak Meratus, and Dayak Ngaju. Examples of sub-ethnic Dayak Ngaju inhabit Central Kalimantan region, especially East Kotawaringin district. Although ethnic Dayak Ngaju residents who are still very thick with the tradition of ancestors are a little bit contrary to the teachings of Islam, but that does not mean Islam does not grow there. In fact, Islam grows rapidly and becomes the largest religion in East Kotawaringin with $86.95 \%$ of the total population of 426,176 people in 2016 . Now, Islam is a religion with the most adherents is because of persistence of the ulama who has the background of various Islamic boarding school in Java and Banjarmasin. This research is a qualitative research with the method of Ethnography of Communication. With the method of communication ethnography, researchers can see how the process of delivering da'wah messages from ulama 'to the people around the Dayaknese especially so that Islam can grow well there. Ethnographic studies attempt to examine a particular cultural group based on observations and the presence of researchers in the field within a certain time.
\end{abstract}

Keywords—ulama; da'wah; ethnography; dayaknese; Islam

\section{INTRODUCTION}

Taking da'wah duties is a noble task performed by religious leaders. The duty of true da'wah is the obligation of every Muslim, but in fact not all Muslims are able to preach but only partly. The da'i in particular, is now required to better understand the targets of da'wah according to the characteristics and background so that the message of da'wah can be conveyed and accepted.

In this study, researchers examined a process of dakwah communication carried out by ulama 'immigrants who come and live in a civilized society order that is Dayak Ngaju ethnic people who still retain the customs of their ancestral heritage. Furthermore, the process of delivering the message of dakwah done by the ulama took place politely and did not offend or necessarily remove the cultural heritage of Dayak Ngaju Ethnic which is still deeply rooted in every aspect of life of local people. In short, the ulama persistent preaching da'wah while maintaining the wisdom of local culture.
Meanwhile, according to some experts' terminology, da'wah has some description. Da'wah is the effort of the ulama and people who have the knowledge of Islam to give teaching to the general public in accordance with the ability possessed about the things they need in world and religious affairs [1]. Meanwhile, da'wah is the process of Islamic teachings in the plains of human life with methodological strategies, and the system taking into account the religious-socio-psychological dimensions of individuals or communities to achieve maximum targets [2]

According to Jamaluddin Kafie (1993) da'wah is an activity system of a gsroup or a group of Muslims as an actualization of manifestation in a certain form manifested in order to be able to touch the heart and soul of a person, a family, a group, mass and human society, in order to influence the behavior to achieve a certain goal [3]

Culture is something that is shared by a group of people, so that culture is the result of interaction between individuals [4]. Anthropologist Rosalie Wax [5] defines culture as a fact of "shared meaning", so talking about culture means talking about a group of people, because there is something shared and shared.

Culture manifests itself in patterns of language and in the form of activities and behaviors that serve as a model for adjustment and communication styles that enable people to live in a society in a certain geographic environment at a certain level of technical development and at a particular moment [6].

Philipsen (1987) has implicitly proposed a taxonomy of interrelated cultures to be established [7]. He interpreted three different ways to manifest a true culture:

- Culture as a human community supported by a social identity that shares with interconnected memories.

- Culture as a conversation or representation of patterns that play the role of the experience of human life.

- Culture as code or a system of values, meanings and ideal and other images.

The ulama who is commonly called 'ustadz' by local residents have the spirit and persistence in preaching. According to them, preaching in the midst of certain ethnic communities that are still very thick with the culture of the ancestors is more difficult than preaching in the midst of 
modern civilized city society so it is needed extra sincerity and extra effort so that da'wah goal can be achieved.

\section{RESEARCH METHOD}

\section{A. Ethnography of Communication}

This research uses a qualitative approach, following the ethnographic tradition of communication. Ethnography is an empirical and theoretical approach aimed at obtaining an indepth description and analysis of culture based on intensive fieldwork [8].

The inventor of ethnography communication is Dell Hymes. He proposes that formal linguistics alone is not enough, he argues that communicating cultures have different ways, but all forms of communication require a shared code, the perpetrator communicates using code, a tool, state, form of message, topic, and an event created with a message spreading [9].

Ethnographic communication is rooted in language and social interaction terms in the qualitative research rules of communication. His research follows the traditions of psychology, sociology, linguistics, and anthropology. The ethnography of communication is focused on cultural codes and rituals [10].

Researchers use this method to examine the forms of communication used by members of a cultural community. This method can be used for research in the level of group / organizational communication, or to approach groups or organizations culturally and religiously and culturally.

In the classification of theories, ethnography of communication in minor groups includes into theories of cultural interpretation [8]. While in the major group, ethnography of communication belongs to experience and interpretation theories, whereas in the methodological group, ethnographic communication along with phenomenological research, grounded research, and inquiry of heuristics, are within the scope of the interpretive methodology. The ethnography of communication is the application of ethnographic methods to the patterns of group communication. Ethnography arises from cultural anthropology. Etno means people or folk, while graphics refer to the description of something. Ethnography therefore means a culture and an understanding of the way of life of others from the side of the native's point of view.

Ethnographic research is cyclical rather than linear as any other social research [11]. Methods of data collection in the stages of this study are by:

- Choose the subject of ethnographic research. The subject of this research is the Dayak Ngaju ethnic community living in the suburbs.

- Submission of inquiries (in-depth interviews). Interviews in the ethnography of communication can take place as long as the researcher conducts field observations, both to the surrounding community (general respondent) and specially planned, wanted and determined respondents to be interviewed for example influential central figures in the region. It depends on the researcher's need for data in the field (Kuswarno: 2008). Informants in this level are local residents, customary heads called Damang Adat Dayak (leader of the Dayaknese harmony), Ulama and some people of Dayaknese.

- Data collection (by in-depth interview, observation, field notes, documentation, internet searching). Researchers conducted data collection with interview to some informant, then do the observation from October 2017 to February 2018 by observing directly and living with the Dayak Ngaju ethnic community. Collecting field data by documenting the activities of citizens, as well as traditional ceremonies.

- Data analysis. In this research is use interactive analysis [12]. Basically, the technique of this analysis consists of 3 components: data reduction, data display, and (drawing and verifying conclusion)

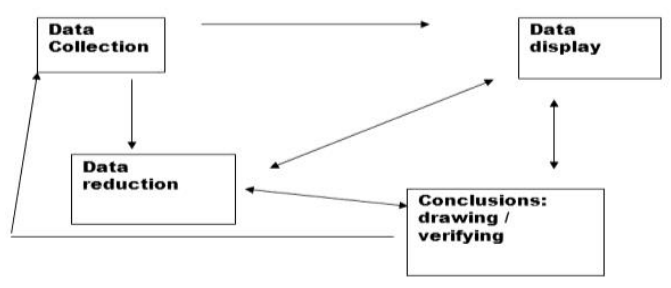

Fig. 1. Overview of qualitative analysis

\section{B. Data Validity}

Triangulation is a method used in qualitative research to examine and establish validity by analyzing from multiple perspectives. Validity in qualitative research can be seen referring to whether the research findings accurately reflect the situation and supported by evidence.

Scientific research always requires validity for the data as well as the findings produced. Because this research is basically a qualitative research then to obtain a guarantee of validity, such as the usual qualitative research, is to use triangulation techniques. In qualitative research, four techniques of triangulation are triangulation method, triangulation among researchers, triangulation of data sources and theory triangulation. In this case, this research uses data triangulation technique (source).

Triangulation of Data Sources is exploring the truth of certain information through various methods and sources of data acquisition. For example, in addition to interviews and observations, researchers may use participant observation, written documents, archives, historical documents, official records, personal notes or writings and drawings or photographs. Of course, each way it will produce different evidence or data, which will then provide different insights about the phenomenon being studied. Those views will give birth to the breadth of knowledge to obtain reliable truth [13]. 
In this study, researchers collect interviews using a recording on a mobile phone then arrange it in the form of verbatim. The observation was done by the researcher directly observation by coming to residential location of Dayak Ngaju ethnic community and also involved in some Islamic activities there, for example: routine recitation, children TPQ activities, tahlilan, yasinan, and so on.

\section{RESUlt AND DiscUSSION}

All efforts have been made by the 'ulama' in delivering the message of da'wah. The 'ulama's persistence' can be seen when some Dayak ethnic groups show contradictory attitude as a response of Islamic activity initiated by the 'ulama' and made routine. The disagreement was realized by forbidding the adzan of salat 5 times loudly because it's disturbing their serenity and making a lie for example is a recent allegation to the 'ulama' that some Muslims have damaged the sacred statue of "Sapundu" placed in front of the house of Dayak ethnicity, which is used to bind sacrificial animals in traditional ceremonies of "Tiwah".

On the other hand, the ulama are often involved in Dayak Ngaju ethnic community in each ceremony of Tiwah become one of 'media' da'wah of ulama in the middle of rejection of application of Islamic values which sometimes still happened. Tiwah is the process of transferring the bones / skulls of family members who have long died from the grave to be placed into the stumbling block. In this ceremony, there is a process of killing the livestock that is usually buffalo as a cult and then the meat is distributed to all the relatives involved in the procession.

The buffalo is not slaughtered by way of syari'at Islam, but customarily with a big spear. The ulama only acted as prayers during the closing session of the event. Other da'wah done by ulama other than tausiyah, as well as traditional ceremonies is through the arts. In Mentawa Hilir sub-district, ulama teaches the art of rebana or hadrah to the children of Dayak tribe whose special tools are imported from Java. The art of the children's rebana in addition to the Islamic songs of Arabic lavish, as well as Banjar-Dayak songs composed by his poetry that teaches good manners, teaches five prayers, and so on. For example, in the song "Ulun Anak Islam" created by a ulama there, is a Banjar-speaking song depicting a child who learns monotheism at the basic level by believing Allah one-on-one God, his religious Islam, and his Prophet Muhammad.

Among the Dayak Ngaju ethnic who have either embraced Islam or who still embrace the religion of Kaharingan belief, the central figure who has the power to direct and influence the

${ }^{1}$ Tiwah is a traditional ceremony performed by the Dayak Ngaju people of Hindu Kaharingan in order to move the bones of family members who have died long ago into the "sandung" placed in front of their home page. Tiwah custom ceremony is usually done for 5 to 7 days in a row. Tiwah ceremony is aimed to deliver the soul or spirit of the deceased human to the destination is Lewu Tatau He Rumpang Bone, Rundund Raja He Kamalesu Uhate, Lewu Tatau Habaras Bulau, Habusung Hintan, Lempang Lamiang or Lewu Liau which is located in the seventh sky (nirvana). While Tiwah ceremony has not been implemented, the Dayak Kaharingan people believe that the human spirit cannot reach nirvana (heaven). people is Damang Adat (head of harmony of adat) and ulama 'who live in his environment. The 'rantau' ulama referred to in this study are ustadz / da'i originating from Java or from Banjarmasin with educational backgrounds from a number of famous pesantren (pesantren) of the great kyai care that gave birth to many santri who competed in a number of religious fields: the science of tafsirul qur 'an, tafsirul hadith, tahfidzul qur'an, da'wah, and others.

\section{A. The role of Ulama.}

To obtain valid data, in this study researchers interviewed some scholars from several mosques / boarding schools. These scholars are involved in various da'wah activities in the midst of the Dayak Ngaju ethnic community. At least, researchers successfully interviewed 5 ulama with educational background from various well-known 'pondok pesantren' in Java and Banjarmasin.

Researchers summarize that according to the scholars the greatest challenge in the process of da'wah activities in the midst of Dayak ethnic are some teachings of Islamic teachings that are taught not in accordance with the local culture customs. Very easy to find dogs or wild boars roam around the settlement of citizens and not a few are left wandering around musala or mosque. Even before it was said that there had been little resistance from the people when their dogs entered the mosque and officers takmir mosque embossed emotion. And in every celebration of either marriage or other traditional ceremonies, the host citizens always slaughter the pigs for consumption.

A variety of responses emerged from citizens in every Islamic religious activity initiated by the scholars. There is a group of citizens who feel that their customary existence is threatened by others who are neutral. The group of people who feel threatened this usually makes the act by spreading slander.

The scholars conveyed, the transfer of beliefs from Kaharingan became a significant Muslim although it cannot be known the exact number of how much increase each year because there is no official record of the relevant government, but the Islamic nuance is now felt in the life of the Dayak community thanks to the scholars who with persistent to live the mosque or musala as the center of the activities of Muslims there.

\section{B. Responses of Dayak Ethnic Residents.}

As mentioned above, citizens' responses are diverse. The elderly is usually antipathic to the activities or messages of preaching that the scholars present, while the younger ones are better educated, accepting and being warmer towards the scholars and to other Muslim citizens. Uniquely, the Leader Damang which is the leader of harmony Dayak and believe in Kaharingan religion actually behave well towards the scholars and support activities of Islamic religion because it feels with the presence of the scholars and the atmosphere of Islamic life, the atmosphere is more conducive and orderly. For example, during Ramadan, every tarawih, musala or mosque always holds a tadarus together and turns on the sound speakers to the mosque and can be heard by the residents, some Dayak ethnic 
and also the Damang Leader feel happy because the atmosphere is alive even at midnight and feel safe awake.

\section{Communication Strategy}

To conduct an effective da'wah message submission, a good communication strategy is required. Strategy refers to the overall communication approach to be taken in order to face the challenges that will be faced during the communication process. Various approaches can be done depending on the situation and conditions, for example in this approach using a cultural approach where researchers see that scholars learn to understand the cultural heritage of Dayak ethnic ancestors so that the message of propagation can be delivered in a polite manner.

One of these approaches can be considered as the basis of a strategy and serves as a framework for further communication planning. A strategy should present the whole direction for initiatives, conformity with available resources, minimize resistance, reach out to target groups, and achieve the goals of communication initiatives.

The core strategy is planning or planning and management to achieve a goal that can only be achieved through operational tactics [14]. A communication strategy should include everything needed to know how to communicate with a target audience. The communication strategy defines the target audience, the actions it will take, telling how target audiences will benefit from their perspective, and how larger target audiences can be reached more effectively.

\section{CONCLUSION}

From the description of the above research results, it can be seen that the Islamic religion has a good development. This is because according to some local religious scholars not a few ethnic Dayak Kaharingan religions finally decided to embrace Islam and the feel of Islamic life that feels so much different than a few years ago. The Dayak ethnic community seems to have begun to accept the presence of Islam and ulama 'in the midst of their lives, but some still feel threatened by the growing presence of Islam so that it is contrary towards the ulama. Obviously, we can conclude that the Islamic religion can continue to grow thanks to the persistence of the scholars who do not despair in da'wah.

The ulama' remain polite even though there are sometimes contradictions and it seems that polite attitude can become the ultimate weapons of the 'ulama' in preaching so that Islam can continue to grow and grow very well in East Kotawaringin. For the ulama a small upheaval of some people who are less fond of the presence of scholars does not become a significant obstacle and assume the commonplace with the notion of primordialism of the Dayak Ngaju ethnic community as' indigenous residents of Borneo who are still trying to keep the inheritance customs and beliefs of the teachings new arrivals brought.

\section{ACKNOWLEDGMENT}

This research has been reviewed and approved by thesis supervisor of Communication Science of Sebelas Maret University Surakarta.

\section{REFERENCES}

[1] Abu Bakr Zakaria, Al-Da'wah ila al-Islam. Kairo: Maktabah Dar al'Arubat, 1962.

[2] Nur Syam, Filsafat Dakwah Pemahaman Filosofis tentang Ilmu Dakwah. Surabaya: Jenggala Pustaka Utama, 2003.

[3] Jamaluddin Kafie, Psikologi Dakwah. Surabaya: Penerbit Indah, 1993.

[4] Engkus Kuswarno, Etnografi Komunikasi: Pengantar dan Contoh Penelitiannya. Bandung: Widya Padjadjaran, 2011.

[5] Soerjono Soekanto. Sosiologi Suatu Pengantar. Jakarta: Raja Grafindo Persada, 1998.

[6] Destien Mistavakia Sirait and Dasrun Hidayat,"Pola Komunikasi Pada Proses Mangulosi Dalam Pernikahan Budaya Adat Batak Toba,” Jurnal Ilmu Komunikasi (J-IKA), vol 2, no 1, 2015.

[7] G Phillipsen. The prospect for cultural communication. In D. L. Kincaid (Ed.), Communication theory: Eastern and Western perspectives. San Diego: Academic Press, 1987.

[8] Stephen W Littlejohn and Karen A. Foss, Teories of Human Communication 10th edition. Illinois: Waveland Press, Inc., 2011.

[9] Tina Kartika, "Pola Komunikasi Etnis Besemah (kajian Etnografi Komunikasi Pada Kelompok Etnis di Pagaralam Sumatera Selatan)," Jurnal Kom dan Realitas Sosial. Jurnal Ilmu Komunikasi. Prodi FISIP Universitas Bandar Lampung, vol 4, no 4, April 2012.

[10] Kiki Zakiah Darmawan, Penelitian Etnografi Komunikasi, Jurnal Komunikasi, vol 9, no 1, 2005.

[11] Jb Spradley, Participant Observation. Holt, Rinehart and Winstons. 1980.

[12] M.B. Milles and M.A. Huberman, Qualitative Data Analysis. London: Sage Publication, 1984.

[13] Mudjia Rahardjo, Triangulasi Dalam Penelitian Kualitatif. Diakses dari http://www.uin-malang.ac.id/r/101001/triangulasi-dalam-penelitiankualitatif.html, 2010.

[14] Onong Uchjana Effendi, Ilmu Komunikasi Teori dan Praktek. Bandung: Remaja Rosdakarya. 1984. 